\title{
Predicting Heart Failure Events in Patients with Coronary Heart Disease and Impaired Glucose Tolerance: Insights from the Acarbose Cardiovascular Evaluation (ACE) Trial
}

\section{Malgorzata Wamil}

Great Western Hospitals NHS Foundation Trust

John J. V. McMurray

University of Glasgow Institute of Cardiovascular and Medical Sciences

Charles A.B. Scott

University of Oxford

Ruth L. Coleman

Churchill Hospital

\section{Yihong Sun}

China-Japan Friendship Hospital

\section{Eberhard Standl}

Helmholtz Zentrum Munchen Institut fur Diabetesforschung

\section{Lars Rydén}

Karolinska Institutet

Rury R Holman ( $\nabla$ rury.holman@dtu.ox.ac.uk)

University of Oxford https://orcid.org/0000-0002-1256-874X

Original investigation

Keywords: heart failure, coronary heart disease, impaired glucose tolerance (IGT), randomised controlled trial, acarbose

Posted Date: July 10th, 2020

DOl: https://doi.org/10.21203/rs.3.rs-40817/v1

License: (9) (1) This work is licensed under a Creative Commons Attribution 4.0 International License. Read Full License 
Version of Record: A version of this preprint was published at Diabetes Research and Clinical Practice on December 1st, 2020. See the published version at https://doi.org/10.1016/j.diabres.2020.108488. 


\section{Abstract}

BACKGROUND Heart failure is a fatal complication of type 2 diabetes but little is known about its incidence in patients with impaired glucose tolerance (IGT). We used Acarbose Cardiovascular Evaluation (ACE) trial data to identify predictors of hospitalisation for heart failure (hHF) or cardiovascular (CV) death in patients with coronary heart disease (CHD) and IGT randomized to acarbose 50mg TID or placebo.

METHODS Independent hHF or hHF/CV death risk factors were determined using Cox proportional hazards models, with participants censored at first hHF event, CV death, or end of follow-up. Baseline variables evaluated included age, sex, body mass index, smoking, plasma creatinine, prior CV events, fasting and 2-hour post-load glucose, and $\mathrm{HbA}_{1 \mathrm{c}}$. Those with nominal univariate associations $(\mathrm{P}<0.1)$ were entered into a multivariate model, with $\mathrm{P}<0.05$ required for retention. Recurrent hHF events were analysed using the Andersen-Gill model, a generalisation of the Cox proportional hazards model, and logistic regression was used for death following hHF.

RESULTS During median 5 years follow-up, hHF/CV death occurred in 393 (6.0\%) ACE participants (triggered by $138 \mathrm{hHF}$ events and $255 \mathrm{CV}$ deaths). Significant hHF/CV death multivariate predictors were higher age and plasma creatinine, as well as prior heart failure (HF), myocardial infarction (MI), atrial fibrillation (AF) and stroke. Acarbose, compared with placebo, did not reduce hHF/CV death (hazard ratio [HR] $0.89,95 \% \mathrm{Cl} 0.64-1.24, \mathrm{P}=0.48)$ or hHF (HR 0.90, 95\% Cl 0.74-1.10, $\mathrm{P}=0.32)$. Forty of the 138 participants who experienced hHF had ${ }^{3} 2$ admissions, and 58 died. No significant effect of acarbose, compared with placebo, was seen for recurrent hHF (HR 1.19, 95\% Cl 0.92-1.55, $p=0.19$ ), or for all-cause mortality (odds ratio $1.49,95 \% \mathrm{Cl} 0.75-2.95, \mathrm{p}=0.25$ ).

CONCLUSIONS Patients with CHD and IGT at greater risk of hHF/CV death were older with higher plasma creatinine, and had prior HF, MI, AF or stroke. Addition of acarbose to optimized CV therapy did not reduce the risk of hHF/CV death or hHF.

Clinical Trial Registration: ClinicalTrials.gov, number NCT00829660, and the International Standard Randomised Controlled Trial Number registry, number ISRCTN91899513.

\section{Background}

It is well known that individuals with type 2 diabetes (T2D) have a higher incidence of heart failure than those without.(1) Less is known, however, about the relationship between impaired glucose tolerance (IGT) and heart failure incidence, and whether treating IGT to delay or prevent development of T2D might reduce the incidence of heart failure. China has one of the highest rates of IGT and new-onset T2D in the world.(2) In addition, the China Heart Survey showed that the prevalence of IGT is significantly higher in individuals with coronary heart disease (CHD), compared with those without CHD.(3) Thus, the combination of CHD and IGT potentially identifies individuals at a greatly increased risk of developing heart failure. 
The Acarbose Cardiovascular Evaluation (ACE) trial was a randomized, double-blind, placebo-controlled, phase 4 cardiovascular outcome trial that randomized Chinese patients with CHD and IGT to acarbose or placebo designed primarily to assess whether acarbose could reduce the frequency of cardiovascular events and, secondarily, reduce the incidence of type 2 diabetes.(4-6) Acarbose is alpha-glucosidase inhibitor that reduces postprandial hyperglycemia by delaying carbohydrate digestion and absorption after meals.(7) In a meta-analysis of seven randomized controlled trials of acarbose, the incidence of heart failure was numerically but not significantly lower compared with placebo.(8)

Using ACE data, we aimed to identify independent baseline predictors for a composite endpoint of incident hospitalisation for heart failure (hHF), or incident hHF or cardiovascular (CV) death in this population, and to assess the impact of post-prandial glucose lowering with acarbose on this outcome, compared with placebo. We also investigated the cumulative risk of hHF, recurrent hHF (given the competing risk of death), and death following hHF, to determine the total burden of hHF in this population.

\section{Methods}

\section{The ACE trial design}

The design and results of the ACE trial have been published previously. $(4,6)$ In brief, it was a prospective, double blind, randomized, multi-centre, cardiovascular intervention trial that enrolled 6,522 patients aged 50 years or more with established CHD and IGT. CHD was defined as: acute myocardial infarction (MI), unstable angina (UA) or stable angina. IGT was diagnosed on a single 70g OGTT, defined as a 2-hour plasma glucose ( $2 \mathrm{HPG}$ ) value $\geq 7.8 \mathrm{but}<11.1 \mathrm{mmol} / \mathrm{l}$ and a fasting plasma glucose $(\mathrm{FPG})<7.0 \mathrm{mmol} / \mathrm{I}$ within six months prior to enrolment. The primary ACE trial outcome was a five-point composite major adverse cardiovascular event (MACE5) outcome (defined as any of CV death, non-fatal MI, non-fatal stroke, hospitalisation for UA or hHF). Pre-specified secondary endpoints included a diagnosis of T2D, allcause mortality and analysis of the individual MACE5 components.

\section{Outcomes}

The four pre-specified outcomes for this analysis were: i) Incident hHF; ii) A composite of hHF or CV death (to account for a portion of the competing risk of death); iii) Recurrent hHF; iv) Death following hHF. Incident hHF was defined by the ACE trial Cardiovascular Event Adjudication Committee (CVEAC) charter as an emergency/unplanned admission to the hospital setting that resulted in fulfilment of at least one of the following three criteria: i) Manifestation of new or worsening heart failure (HF); ii) New or additional therapy specifically for the treatment of HF; iii) That the CVEAC should be satisfied that HF was the primary reason for hospitalisation.

\section{Statistical analysis}


Continuous baseline variables were summarized using means and standard deviations, except where noted otherwise. Categorical variables were summarized as counts and percentages. We identified potential independent predictors using a Cox proportional hazards model by first testing pre-specified variables for univariate associations with each of the four outcomes. Nominally statistically significant variables $(P<0.1)$ were then tested in a multivariate model and required to achieve $P<0.05$ to be considered as independent predictors. Potential risk factors examined were: age, sex, body mass index $(\mathrm{BMI})$, race, waist circumference, smoking status, plasma creatinine, systolic blood pressure (SBP), haemoglobin, $\mathrm{FPG}, 2-\mathrm{HPG}, \mathrm{HbA}_{10}$, allocation to acarbose or placebo, and presence of prior CV events, atrial fibrillation (AF) or hypertension, as well as use of statins, aspirin or anti-hypertensive medications. Recurrent hHF events were analysed using the Andersen-Gill model, a generalisation of the Cox proportional hazards model.(9) This model is appropriate as correlations among events for each individual are induced by measured covariates. Thus, the dependence is captured by specifying timedependent covariates such as number of previous events. To identify predictors of death following hHF we used logistic regression analysis, with $\mathrm{P}<0.1$ indicating a univariate association and $\mathrm{P}<0.05$ required for retention in a multivariable model.

\section{Results}

\section{Patient Characteristics}

Mean (SD) age was 64.3 (8.1) years, BMI $25.4(3.1) \mathrm{kg} / \mathrm{m}^{2}$, median (IQR) eGFR $88.5 \mathrm{ml} / \mathrm{min} / 1.73 \mathrm{~m}^{2}$ (74.8-103.3), and $73 \%$ of participants were male (Table 1). There were 243 (3.7\%) of ACE participants with a history of HF at baseline.

\section{Predictors of hHF}

During median 5.0 years follow-up, 138 (2.1\%) participants experienced one or more hHF events $(0.46$ first events per 100 person-years follow-up). Baseline characteristics for those who did, or did not, experience hHF during the trial are listed in Table 1. Participants with, compared with those without, incident hHF were older, had lower mean haemoglobin, higher mean plasma creatinine values, and were more likely to have had a prior MI ( $54.4 \%$ vs. $41.3 \%, p=0.0021)$, UA $(26.8 \%$ vs. $42 \%, p=0.0004), H F(19.6 \%$ vs. $3.4 \%, p<0.0001)$ or AF $(16.7 \%$ vs. $3.6 \%, p<0.0001)$. Participants with incident hHF were also more likely at baseline to be taking ACE inhibitors/angiotensin receptor blockers, diuretics, nitrates or digitalis.

Univariate associations of variables with hHF are listed in Table 2. Of these, only higher age, higher plasma creatinine, lower haemoglobin, prior HF, prior MI and prior AF remained as statistically significant independent risk factors in multivariate models (Table 3).

\section{Predictors of hHF/CV death}

The composite hHF/CV death outcome occurred in 393 (6.0\%) ACE participants during median 5.0 years follow-up, triggered by $138 \mathrm{hHF}$ events and $255 \mathrm{CV}$ deaths. Univariate hHF/CV death predictors were: 
higher age, higher BMI, higher plasma creatinine, lower haemoglobin, prior HF, prior MI, prior UA, prior AF, prior stroke/TIA and hypertension (Table 2). Of these, only age, plasma creatinine, prior HF, prior MI, prior $\mathrm{AF}$ and prior stroke remained as statistically significant independent risk factors in multivariate models (Table 3). Measures of glycemia (FPG, 2HPG, $\mathrm{HbA}_{1 \mathrm{c}}$ ), lipids, SBP, BMI and waist circumference were not associated independently with hHF/CV death.

\section{Recurrent hHF events}

A total of $232 \mathrm{hHF}$ events occurred in 138 participants during the study, of whom 40 (29.0\%) experienced $\geq 2$ events (94 recurrent events in total) with a median (IQR) of $3(2-4)$ hHF events during follow-up.

\section{Mortality following incident hHF}

The proportion of participants who died following a first hHF event was similar in those with or without prior HF (Table 4). A multivariate analysis of risk factors for case-fatality following a first hHF event showed that significant predictors were higher age (Odds Ratio [OR] 1.08, 95\% $\mathrm{Cl}(1.03-1.13), \mathrm{P}=0.003$ ) and higher plasma creatinine values (OR 1.02, 95\% Cl (1.00-1.03), $\mathrm{P}=0.040)$.

\section{Effect of acarbose}

Acarbose, compared with placebo, had no statistically significant effect on incident hHF (HR 0.89, 95\% Cl 0.64-1.24, $\mathrm{P}=0.48)$ or recurrent hHF (HR 1.19, 95\% Cl 0.92-1.55, $\mathrm{P}=0.19)$. Acarbose, compared with placebo, also had no effect on $\mathrm{hHF} / \mathrm{CV}$ death (HR 0.90, 95\% $\mathrm{Cl} 0.74-1.10, \mathrm{P}=0.32)$ (Figure 1) or death following hHF (OR 1.49, 95\% Cl 0.75-2.95, P=0.25).

\section{Discussion}

This is the first study describing incident hHF and associated mortality in a large Asian population with CHD and IGT. In Chinese patients with CHD and IGT, we show that higher age, higher plasma creatinine, lower haemoglobin, prior $\mathrm{HF}$, prior $\mathrm{Ml}$ and prior $\mathrm{AF}$ were all predictive of incident $\mathrm{hHF}$, and that higher age, higher plasma creatinine, prior $\mathrm{HF}$, prior $\mathrm{Ml}$, prior $\mathrm{AF}$ and prior stroke were predictive of $\mathrm{hHF} / \mathrm{CV}$ death. Death following hHF was predicted by older age and higher plasma creatinine. Allocation to acarbose 50 mg TID, compared with placebo, in the ACE trial, $(4,6)$ showed no risk reductions for incident hHF, recurrent $\mathrm{hHF}$ or for $\mathrm{hHF} / \mathrm{CV}$ death despite an $18 \%$ reduction in the risk of T2D.(5)

Our within trial observations are in accord with those seen in the NAVIGATOR trial, which also showed no reduction in hHF in patients with IGT and CHD despite the improved glycaemic control achieved with nateglinide, a short-acting insulin secretagogue. $(10,11)$ Lowering post-prandial glycemia has been suggested as a way to reduce HF risk, $(12,13)$ but neither increasing post prandial insulin concentrations with nateglinide, nor using the insulin-sparing mode of action of acarbose to do so, reduced the risk of hHF in populations with IGT and CHD (Figure 2). 
Similar findings have been reported consistently with other glucose-lowering therapies (DPP-4 inhibitors and insulin) in patients with established T2D $(10,14-16)$ suggesting that therapeutic strategies focused on glycaemic control in T2D have a neutral effect on incident hHF or hHF-related death. Additionally, despite the reduced risk for new-onset diabetes seen with acarbose in the ACE trial, the within-trial risk of incident and recurrent hHF was unchanged. IGT is a precursor to T2D and has been shown to be a risk factor for cardiovascular morbidity. Thus, it is plausible that metabolic alterations leading to myocardial damage may start at an earlier stage, even before the formal diagnosis of T2D. In the ACE trial, $2.1 \%$ of participants experienced $\geq 1$ episode of hHF, equating to 0.46 cases per 100 person-years of follow-up.(5) The hHF rate was similar in the NAVIGATOR trial ( 0.36 cases per 100 person-years of follow-up). For comparison, in the EXAMINE and the ELIXA trials, 3.6\% and $8.3 \%$ of patients with acute coronary syndrome and established T2D experienced $\geq 1$ episode of hHF respectively, equating to 1.09 and 1.94 cases per 100 person-years of follow-up. $(17,18)$ The higher hHF rates observed in T2D patients, compared with IGT subjects, likely reflects their more advanced CHD and myocardial damage, which could be secondary to longer duration of abnormal glycaemic exposure.

$\mathrm{MI}$ is a major predictor of HF, as confirmed in our study, but given no CV benefit was evident in the three $\sim 5$-year duration randomized controlled trials that have compared intensive with conventional glycaemic control in T2D patients (19-21), it may not be surprising that improving glycaemic control over a similar timescale in ACE subjects with CHF and IGT had little impact on incident hHF. In the longer term, the UKPDS has demonstrated a legacy effect of the benefits of earlier improved glycaemic control with sulfonylurea or insulin in people with newly-diagnosed T2D. The UKPDS showed a 15\% lower risk of MI (P $=0.01$ ) over a median follow-up of 16.8 years, but did not report HF rates. (22)

Considering the increasing burden of HF events observed in people with IGT or T2D, early screening for those factors contributing to an individual's heightened risk needs careful consideration. Several studies have shown that prior HF is a powerful independent predictor of readmission $(23,24)$. Our study is in accord with these observations, confirming that in a Chinese population with CHD and IGT a prior history of HF was the most significant predictor of hHF.

In our multivariable model, older age and increased plasma creatinine were also major predictors for incident hHF and subsequent case fatality. Kidney dysfunction is common in elderly populations and strongly associated with short-term and long-term outcomes in patients with HF (25).

In the high-risk ACE trial population with CHD and IGT, previous MI but not angina was independently associated with hHF. Of note, measures of glycaemic control, weight and blood pressure showed no association with hHF. This may reflect the fact that ACE trial participants were exceptionally wellmanaged with respect to administration of evidence-based secondary CV prevention therapies, as there was a protocol-mandated 4-week CV risk factor optimisation run-in period preceding randomisation.(4) Hence, additional HF risk factors such as age and plasma creatinine may become more prominent with good control of traditional CV risk factors such as hypertension, dyslipidaemia and smoking. However, an alternative interpretation of the ACE and the NAVIGATOR trial findings might be that in populations 
with CHD and IGT already established on maximum CV secondary prevention, those with kidney disease have a poorer prognosis with a higher risk of hHF and CV death. In this context it is important to note novel glucose-lowering treatments with SGLT-2 inhibitors with their promising beneficial renal profile have been shown to be of particular value in reducing the risk of HF in people with or without T2D. (26-30)

Of note, there were some differences between the major predictors for hHF reported by the NAVIGATOR and the ACE trials. NAVIGATOR, which included 9,306 participants with IGT and either CV disease or CV risk, confirmed waist circumference among three major predictors of hHF (11). In the ACE trial by contrast, neither waist circumference nor BMI were independently associated with an increased hHF rates, possibly due to phenotypic differences in those recruited. Whilst NAVIGATOR recruited subjects with a mean $B M I \geq 30 \mathrm{~kg} / \mathrm{m}^{2}$, the mean BMI of the ACE Chinese participants was $25.4 \mathrm{~kg} / \mathrm{m}^{2}$. This could suggest that the mechanisms leading to the development of HF in an Asian 'lean' cardiometabolic phenotype are distinct from those in Western patients whose IGT is closely linked to obesity.

Epidemiological data strongly support the role of $\mathrm{AF}$ in the development of $\mathrm{HF}$ in people with diabetes. The pathophysiology and risk factors for AF and HF are closely aligned, with affected patients usually being elderly with multiple comorbidities $(31,32)$. In our study, we found prior AF to be an independent predictor of incident hHF, as did NAVIGATOR. (11)

These analyses have several limitations. Firstly, of the entire spectrum of heart failure events the ACE trial only examined hHF events. Restricting HF outcomes to hospitalised cases does not reflect contemporary management of $\mathrm{HF}$, with an on-going shift towards community and ambulatory care. Secondly, left ventricular ejection fraction data was not collected so we do not know whether participants with incident hHF had a reduced or preserved ejection fraction. While T2D and IGT are associated with both types of $\mathrm{HF}$, it is likely that adjudicated hHF events represent ischemic cardiomyopathy as the more predominant phenotype. Hence, more subtle changes expected in HF with a preserved ejection fraction, which are frequently observed in the setting of IGT and insulin resistance(33), have not been detected in this trial. Thirdly, any conclusions regarding the predictive role of AF for HF in the ACE and NAVIGATOR populations need to circumspect given the low number of hHF events recorded in both trials.

In conclusion, in Chinese patients with CHD and IGT established on optimal secondary CV risk prevention, we identified higher age, increased plasma creatinine, lower haemoglobin, prior $\mathrm{Ml}$ and prior AF as independent predictors of hHF. Higher age and increased creatinine predicted case fatality. Allocation to acarbose 50mg TID was not associated with reductions in hHF, hHF/CV death, recurrent hHF or death following hHF. These findings will assist health care professionals to risk stratify patients with $\mathrm{CHD}$ and IGT and help identify those that might benefit from early screening for signs of HF. As this study focused on a Chinese population with a lower BMI compared with similar Western cohorts studied to date, any extrapolation of our results should consider the potential influence of phenotypic differences on HF risk.

\section{Abbreviations List}


ACE: Acarbose Cardiovascular Evaluation (ACE)

AF: atrial fibrillation

CHD: coronary heart disease

CV death: cardiovascular death

IGT: impaired glucose tolerance

hHF: hospitalisation heart failure

HR: hazard ratio

Ml: myocardial infarction

UA: unstable angina

TIA: transient ischemic attack

\section{Declarations}

\section{Ethics approval and consent to participate}

The ACE protocol was approved by the University of Oxford Tropical Research Ethics Committee, and by central or local ethics committees (as appropriate) at participating sites. All participants provided written informed consent.

\section{Consent for publication}

Not applicable

\section{Availability of data and materials}

CABS, RLC and RRH had full access to the data.

\section{Competing interests}

The authors declare that they have no competing interests.

\section{Disclosures}

MW, CABS, RLC and YS report no disclosures.

JJVM reports consulting payments through Glasgow University from Bayer, Cardiorentis, Amgen, Theracos, AbbVie, DalCor Pharmaceuticals, Pfizer, Merck, AstraZeneca, GlaxoSmithKline, Bristol-Myers Squibb, Vifor-Fresenius, Kidney Research UK, Novartis, and Theracos. 
ES reports personal fees from Oxford Diabetes Trials Unit, Bayer, Berlin Chemie, Boehringer Ingelheim, Menarini, Merck Serono, EXCEMED, Novartis, Novo Nordisk, and Sanofi.

LR reports grants from the Swedish Heart Lung Foundation, Stockholm County Council, and Boehringer Ingelheim, and fees for consulting and speaking from Boehringer Ingelheim, Novo Nordisk, Eli Lilly, Merck, and Bayer.

RRH reports research support from AstraZeneca, Bayer and Merck Sharp \& Dohme, and personal fees from Bayer, Intarcia, Merck Sharp \& Dohme, Novartis and Novo Nordisk.

\section{Funding}

The ACE study was funded by Bayer AG.

\section{Authors' contributions}

MW analysed data and wrote the manuscript. CABS and RLC nalysed the data and reviewed the manuscript. JJM and RRH designed the study and reviewed the manuscript. ES, LR and YS contributed to the discussion and reviewed the manuscript.

\section{Acknowledgements}

We thank the patients, without whom this study and these analyses would not have been possible, and the ACE study personnel. RRH is an Emeritus National Institute for Health Research Senior Investigator.

\section{References}

1. McMurray JJ, Gerstein HC, Holman RR, Pfeffer MA. Heart failure: a cardiovascular outcome in diabetes that can no longer be ignored. Lancet Diabetes Endocrinol. 2014;2(10):843-51.

2. International Diabetes Federation. IDF Diabetes Atlas teB, Belgium:, International Diabetes Federation Afhwdo.

3. Hu DY, Pan CY, Yu JM, China Heart Survey G. The relationship between coronary artery disease and abnormal glucose regulation in China: the China Heart Survey. Eur Heart J. 2006;27(21):2573-9.

4. Holman RR, Bethel MA, Chan JC, Chiasson JL, Doran Z, Ge J, et al. Rationale for and design of the Acarbose Cardiovascular Evaluation (ACE) trial. Am Heart J. 2014;168(1):23-9 e2.

5. Theodorakis MJ, Coleman RL, Feng H, Chan J, Chiasson JL, Ge J, et al. Baseline characteristics and temporal differences in Acarbose Cardiovascular Evaluation (ACE) trial participants. Am Heart J. 2018;199:170-5.

6. Holman RR, Coleman RL, Chan JCN, Chiasson JL, Feng H, Ge J, et al. Effects of acarbose on cardiovascular and diabetes outcomes in patients with coronary heart disease and impaired glucose tolerance (ACE): a randomised, double-blind, placebo-controlled trial. Lancet Diabetes Endocrinol. 2017;5(11):877-86. 
7. Bischoff $\mathrm{H}$. The mechanism of alpha-glucosidase inhibition in the management of diabetes. Clin Invest Med. 1995;18(4):303-11.

8. Hanefeld M, Cagatay M, Petrowitsch T, Neuser D, Petzinna D, Rupp M. Acarbose reduces the risk for myocardial infarction in type 2 diabetic patients: meta-analysis of seven long-term studies. Eur Heart J. 2004;25(1):10-6.

9. Andersen PK GR. Cox's regression model for counting processes: a large sample study. Ann Stat. 1982;10(4):1100-20.

10. Group NS, Holman RR, Haffner SM, McMurray JJ, Bethel MA, Holzhauer B, et al. Effect of nateglinide on the incidence of diabetes and cardiovascular events. N Engl J Med. 2010;362(16):1463-76.

11. Wong YW, Thomas L, Sun JL, McMurray JJ, Krum H, Hernandez AF, et al. Predictors of incident heart failure hospitalisations among patients with impaired glucose tolerance: insight from the Nateglinide And Valsartan in Impaired Glucose Tolerance Outcomes Research study. Circ Heart Fail. 2013;6(2):203-10.

12. Shimabukuro M, Higa N, Asahi T, Yamakawa K, Oshiro Y, Higa M, et al. Impaired glucose tolerance, but not impaired fasting glucose, underlies left ventricular diastolic dysfunction. Diabetes Care. 2011;34(3):686-90.

13. Kim J, Nakatani S, Hashimura K, Komamura K, Kanzaki H, Asakura M, et al. Abnormal glucose tolerance contributes to the progression of chronic heart failure in patients with dilated cardiomyopathy. Hypertens Res. 2006;29(10):775-82.

14. Li J, Tong Y, Zhang Y, Tang L, Lv Q, Zhang F, et al. Effects on All-cause Mortality and Cardiovascular Outcomes in Patients With Type 2 Diabetes by Comparing Insulin With Oral Hypoglycemic Agent Therapy: A Meta-analysis of Randomized Controlled Trials. Clin Ther. 2016;38(2):372-86 e6.

15. McGuire DK, Van de Werf F, Armstrong PW, Standl E, Koglin J, Green JB, et al. Association Between Sitagliptin Use and Heart Failure Hospitalisation and Related Outcomes in Type 2 Diabetes Mellitus: Secondary Analysis of a Randomized Clinical Trial. JAMA Cardiol. 2016;1(2):126-35.

16. Investigators OT, Gerstein HC, Bosch J, Dagenais GR, Diaz R, Jung H, et al. Basal insulin and cardiovascular and other outcomes in dysglycemia. N Engl J Med. 2012;367(4):319-28.

17. Zannad F, Cannon CP, Cushman WC, Bakris GL, Menon V, Perez AT, et al. Heart failure and mortality outcomes in patients with type 2 diabetes taking alogliptin versus placebo in EXAMINE: a multicentre, randomised, double-blind trial. Lancet. 2015;385(9982):2067-76.

18. Pfeffer MA, Claggett B, Diaz R, Dickstein K, Gerstein HC, Kober LV, et al. Lixisenatide in Patients with Type 2 Diabetes and Acute Coronary Syndrome. N Engl J Med. 2015;373(23):2247-57.

19. Action to Control Cardiovascular Risk in Diabetes Study G, Gerstein HC, Miller ME, Byington RP, Goff DC, Jr., Bigger JT, et al. Effects of intensive glucose lowering in type 2 diabetes. N Engl J Med. 2008;358(24):2545-59.

20. Patel A, Group AC, MacMahon S, Chalmers J, Neal B, Woodward M, et al. Effects of a fixed combination of perindopril and indapamide on macrovascular and microvascular outcomes in 
patients with type 2 diabetes mellitus (the ADVANCE trial): a randomised controlled trial. Lancet. 2007;370(9590):829-40.

21. Duckworth W, Abraira C, Moritz T, Reda D, Emanuele N, Reaven PD, et al. Glucose control and vascular complications in veterans with type 2 diabetes. N Engl J Med. 2009;360(2):129-39.

22. Holman RR, Paul SK, Bethel MA, Matthews DR, Neil HA. 10-year follow-up of intensive glucose control in type 2 diabetes. N Engl J Med. 2008;359(15):1577-89.

23. Krumholz HM, Parent EM, Tu N, Vaccarino V, Wang Y, Radford MJ, et al. Readmission after hospitalisation for congestive heart failure among Medicare beneficiaries. Arch Intern Med. 1997;157(1):99-104.

24. Krumholz HM, Chen YT, Wang Y, Vaccarino V, Radford MJ, Horwitz RI. Predictors of readmission among elderly survivors of admission with heart failure. Am Heart J. 2000;139(1 Pt 1):72-7.

25. Komukai K, Ogawa T, Yagi H, Date T, Sakamoto H, Kanzaki Y, et al. Decreased renal function as an independent predictor of re-hospitalisation for congestive heart failure. Circ J. 2008;72(7):1152-7.

26. Fitchett D, Zinman B, Wanner C, Lachin JM, Hantel S, Salsali A, et al. Heart failure outcomes with empagliflozin in patients with type 2 diabetes at high cardiovascular risk: results of the EMPA-REG OUTCOME(R) trial. Eur Heart J. 2016;37(19):1526-34.

27. Kosiborod MN, Jhund PS, Docherty KF, Diez M, Petrie MC, Verma S, et al. Effects of Dapagliflozin on Symptoms, Function, and Quality of Life in Patients With Heart Failure and Reduced Ejection Fraction: Results From the DAPA-HF Trial. Circulation. 2020;141(2):90-9.

28. Martinez FA, Serenelli M, Nicolau JC, Petrie MC, Chiang CE, Tereshchenko S, et al. Efficacy and Safety of Dapagliflozin in Heart Failure With Reduced Ejection Fraction According to Age: Insights From DAPA-HF. Circulation. 2020;141(2):100-11.

29. McMurray JJV, DeMets DL, Inzucchi SE, Kober L, Kosiborod MN, Langkilde AM, et al. The Dapagliflozin And Prevention of Adverse-outcomes in Heart Failure (DAPA-HF) trial: baseline characteristics. Eur J Heart Fail. 2019;21(11):1402-11.

30. McMurray JJV, Solomon SD, Inzucchi SE, Kober L, Kosiborod MN, Martinez FA, et al. Dapagliflozin in Patients with Heart Failure and Reduced Ejection Fraction. N Engl J Med. 2019;381(21):1995-2008.

31. van Deursen VM, Urso R, Laroche C, Damman K, Dahlstrom U, Tavazzi L, et al. Co-morbidities in patients with heart failure: an analysis of the European Heart Failure Pilot Survey. Eur J Heart Fail. 2014;16(1):103-11.

32. Chiang CE, Naditch-Brule L, Murin J, Goethals M, Inoue H, O'Neill J, et al. Distribution and risk profile of paroxysmal, persistent, and permanent atrial fibrillation in routine clinical practice: insight from the real-life global survey evaluating patients with atrial fibrillation international registry. Circ Arrhythm Electrophysiol. 2012;5(4):632-9.

33. Dunlay SM, Givertz MM, Aguilar D, Allen LA, Chan M, Desai AS, et al. Type 2 Diabetes Mellitus and Heart Failure, A Scientific Statement From the American Heart Association and Heart Failure Society of America. J Card Fail. 2019;25(8):584-619 


\section{Tables}

Page $13 / 22$ 
Table 1

Baseline characteristics of participants with or without incident hospitalisation for heart failure (hHF) during the trial

\begin{tabular}{|c|c|c|c|c|}
\hline \multirow[t]{2}{*}{ Variable } & \multirow{2}{*}{$\begin{array}{l}\text { All } \\
\text { participants } \\
(n=6522)\end{array}$} & \multicolumn{2}{|c|}{ Incident hHF } & \multirow{2}{*}{$\begin{array}{l}\text { P-value for those with vs. those } \\
\text { without incident hHF }\end{array}$} \\
\hline & & $\begin{array}{l}\text { Yes } \\
(n= \\
138)\end{array}$ & $\begin{array}{l}\text { No } \\
(n= \\
6384)\end{array}$ & \\
\hline $\begin{array}{l}\text { Allocated to } \\
\text { acarbose }\end{array}$ & $\begin{array}{l}3272 \\
(50.2 \%)\end{array}$ & $\begin{array}{l}65 \\
(47.1 \%)\end{array}$ & $\begin{array}{l}3207 \\
(50.2 \%)\end{array}$ & 0.47 \\
\hline Age (years) & $64.3(8.1)$ & $\begin{array}{l}70.6 \\
(8.8)\end{array}$ & $\begin{array}{l}64.2 \\
(8.0)\end{array}$ & $<.0001$ \\
\hline Male & $\begin{array}{l}4760 \\
(73.0 \%)\end{array}$ & $\begin{array}{l}105 \\
(76.1 \%)\end{array}$ & $\begin{array}{l}4655 \\
(72.9 \%)\end{array}$ & 0.41 \\
\hline $\mathrm{BMI}\left(\mathrm{kg} / \mathrm{m}^{2}\right)$ & $25.4(3.1)$ & $\begin{array}{l}25.2 \\
(3.2)\end{array}$ & $\begin{array}{l}25.4 \\
(3.1)\end{array}$ & 0.45 \\
\hline Han ethnicity & $\begin{array}{l}6327 \\
(97.0 \%)\end{array}$ & $\begin{array}{l}135 \\
(97.8 \%)\end{array}$ & $\begin{array}{l}6192 \\
(97.0 \%)\end{array}$ & 0.57 \\
\hline Current smoker & $\begin{array}{l}823 \\
(12.6 \%)\end{array}$ & $\begin{array}{l}17 \\
(12.3 \%)\end{array}$ & $\begin{array}{l}806 \\
(12.6 \%)\end{array}$ & 0.55 \\
\hline SBP $(\mathrm{mmHg})$ & $130(14.2)$ & $\begin{array}{l}128.6 \\
(13.2)\end{array}$ & $\begin{array}{l}129.5 \\
(14.2)\end{array}$ & 0.41 \\
\hline $\mathrm{HBA}_{1 \mathrm{c}}(\%)$ & $5.9(0.7)$ & $\begin{array}{l}5.9 \\
(0.7)\end{array}$ & $5.9(0.7)$ & 0.91 \\
\hline $\mathrm{HBA}_{1 \mathrm{c}}(\mathrm{mmol} / \mathrm{mol})$ & $41(8)$ & $41(8)$ & $41(8)$ & \\
\hline $\mathrm{FPG}(\mathrm{mmol} / \mathrm{L})$ & $5.5(0.8)$ & $\begin{array}{l}5.4 \\
(0.7)\end{array}$ & $5.5(0.7)$ & 0.47 \\
\hline 2HPG (mmol/L) & $9.3(1.1)$ & $\begin{array}{l}9.3 \\
(0.9)\end{array}$ & $9.2(1.0)$ & 0.78 \\
\hline $\begin{array}{l}\text { eGFR } \\
\left(\mathrm{mL} / \mathrm{min} / 1.73 \mathrm{~m}^{2}\right)\end{array}$ & $\begin{array}{l}88(75 \\
103)\end{array}$ & $\begin{array}{l}73(59 \\
89)\end{array}$ & $\begin{array}{l}89(75 \\
103)\end{array}$ & $<.0001$ \\
\hline $\begin{array}{l}\text { Plasma creatinine } \\
(\mu \mathrm{mol} / \mathrm{L})\end{array}$ & $78.9(19.4)$ & $\begin{array}{l}93.0 \\
(27.7)\end{array}$ & $\begin{array}{l}78.6 \\
(19.1)\end{array}$ & $<.0001$ \\
\hline
\end{tabular}

Data are N (\%), Mean (SD) or Median (IQR); Abbreviations: ACE inhibitor- angiotensin converting enzyme, ARB- angiotensin II receptor blocker, AF- atrial fibrillation, BMI- body mass index, eGFRestimated glomerular filtration rate, FPG- fasting plasma glucose, $\mathrm{HBA}_{1 \mathrm{c}}$-haemoglobin $\mathrm{A}_{1 \mathrm{c}}, 2 \mathrm{HPG}-2$ hour plasma glucose, MI- myocardial infarction, SBP-systolic blood pressure, TIA-transient ischaemic attack, UA- unstable angina 


\begin{tabular}{|c|c|c|c|c|}
\hline \multirow[t]{2}{*}{ Variable } & \multirow{2}{*}{$\begin{array}{l}\text { All } \\
\text { participants } \\
(n=6522)\end{array}$} & \multicolumn{2}{|c|}{ Incident hHF } & \multirow{2}{*}{$\begin{array}{l}\text { P-value for those with vs. those } \\
\text { without incident hHF }\end{array}$} \\
\hline & & $\begin{array}{l}\text { Yes } \\
(n= \\
138)\end{array}$ & $\begin{array}{l}\text { No } \\
(n= \\
6384)\end{array}$ & \\
\hline Haemoglobin (g/L) & $\begin{array}{l}141.5 \\
(15.0)\end{array}$ & $\begin{array}{l}134.5 \\
(18.0)\end{array}$ & $\begin{array}{l}141.6 \\
(14.9)\end{array}$ & $<.0001$ \\
\hline $\begin{array}{l}\text { Waist } \\
\text { circumference }(\mathrm{cm})\end{array}$ & $91.2(8.9)$ & $\begin{array}{l}91.0 \\
(8.7)\end{array}$ & $\begin{array}{l}91.2 \\
(8.9)\end{array}$ & 0.76 \\
\hline \multicolumn{5}{|l|}{ Medical history } \\
\hline Prior MI & $\begin{array}{l}2712 \\
(41.6 \%)\end{array}$ & $\begin{array}{l}75 \\
(54.4 \%)\end{array}$ & $\begin{array}{l}2637 \\
(41.3 \%)\end{array}$ & 0.0021 \\
\hline Prior UA & $\begin{array}{l}2715 \\
(41.7 \%)\end{array}$ & $\begin{array}{l}37 \\
(26.8 \%)\end{array}$ & $\begin{array}{l}2678 \\
(42.0 \%)\end{array}$ & 0.0004 \\
\hline Prior stable angina & $\begin{array}{l}1417 \\
(21.7 \%)\end{array}$ & $\begin{array}{l}38 \\
(27.5 \%)\end{array}$ & $\begin{array}{l}1379 \\
(21.6 \%)\end{array}$ & 0.095 \\
\hline Prior AF & $255(3.9 \%)$ & $\begin{array}{l}23 \\
(16.7 \%)\end{array}$ & $\begin{array}{l}232 \\
(3.6 \%)\end{array}$ & $<.0001$ \\
\hline Prior stroke/TIA & $428(6.6 \%)$ & $\begin{array}{l}12 \\
(8.7 \%)\end{array}$ & $\begin{array}{l}416 \\
(6.5 \%)\end{array}$ & 0.31 \\
\hline Prior hypertension & $\begin{array}{l}4274 \\
(65.5 \%)\end{array}$ & $\begin{array}{l}90 \\
(65.2 \%)\end{array}$ & $\begin{array}{l}4184 \\
(65.5 \%)\end{array}$ & 0.058 \\
\hline Prior HF & $243(3.7 \%)$ & $\begin{array}{l}27 \\
(19.6 \%)\end{array}$ & $\begin{array}{l}216 \\
(3.4 \%)\end{array}$ & $<.0001$ \\
\hline \multicolumn{5}{|l|}{$\begin{array}{l}\text { Concomitant } \\
\text { Medication }\end{array}$} \\
\hline Statins & $\begin{array}{l}6066 \\
(93.2 \%)\end{array}$ & $\begin{array}{l}128 \\
(92.8 \%)\end{array}$ & $\begin{array}{l}5938 \\
(93.2 \%)\end{array}$ & 0.85 \\
\hline Aspirin & $\begin{array}{l}6126 \\
(93.9 \%)\end{array}$ & $\begin{array}{l}224 \\
(93.0 \%)\end{array}$ & $\begin{array}{l}5901 \\
(94.1 \%)\end{array}$ & 0.50 \\
\hline Beta blockers & $\begin{array}{l}4301 \\
(66.1 \%)\end{array}$ & $\begin{array}{l}95 \\
(68.8 \%)\end{array}$ & $\begin{array}{l}4206 \\
(66.0 \%)\end{array}$ & 0.49 \\
\hline $\begin{array}{l}\text { Calcium channel } \\
\text { blockers }\end{array}$ & $\begin{array}{l}1905 \\
(29.3 \%)\end{array}$ & $\begin{array}{l}39 \\
(28.3 \%)\end{array}$ & $\begin{array}{l}1866 \\
(29.3 \%)\end{array}$ & 0.79 \\
\hline
\end{tabular}

Data are N (\%), Mean (SD) or Median (IQR); Abbreviations: ACE inhibitor- angiotensin converting enzyme, ARB- angiotensin II receptor blocker, AF- atrial fibrillation, BMI- body mass index, eGFRestimated glomerular filtration rate, FPG- fasting plasma glucose, $\mathrm{HBA}_{1 \mathrm{c}}$-haemoglobin $\mathrm{A}_{1 \mathrm{c}}, 2 \mathrm{HPG}-2$ hour plasma glucose, MI- myocardial infarction, SBP-systolic blood pressure, TIA-transient ischaemic attack, UA- unstable angina 


\begin{tabular}{|c|c|c|c|c|}
\hline \multirow[t]{4}{*}{ Variable } & \multirow{4}{*}{$\begin{array}{l}\text { All } \\
\text { participants } \\
(n=6522)\end{array}$} & \multicolumn{2}{|c|}{ Incident hHF } & \multirow{4}{*}{$\begin{array}{l}\text { P-value for those with vs. those } \\
\text { without incident hHF }\end{array}$} \\
\hline & & Yes & No & \\
\hline & & $(n=$ & $(n=$ & \\
\hline & & 138) & 6384) & \\
\hline Thiazide diuretics & $190(2.9 \%)$ & $\begin{array}{l}10 \\
(7.3 \%)\end{array}$ & $\begin{array}{l}180 \\
(2.8 \%)\end{array}$ & 0.0022 \\
\hline $\begin{array}{l}\text { ACE } \\
\text { inhibitors/ARB's }\end{array}$ & $\begin{array}{l}3839 \\
(58.9 \%)\end{array}$ & $\begin{array}{l}105 \\
(58.5 \%)\end{array}$ & $\begin{array}{l}3734 \\
(76.1 \%)\end{array}$ & $<.0001$ \\
\hline $\begin{array}{l}\text { Non-thiazide } \\
\text { diuretics }\end{array}$ & $141(2.2 \%)$ & $\begin{array}{l}18 \\
(13.0 \%)\end{array}$ & $\begin{array}{l}123 \\
(1.9 \%)\end{array}$ & $<.0001$ \\
\hline Digitalis & $70(1.1 \%)$ & $\begin{array}{l}11 \\
(8.0 \%)\end{array}$ & $\begin{array}{l}59 \\
(0.9 \%)\end{array}$ & $<.0001$ \\
\hline Antiarrhythmic & $94(1.4 \%)$ & $4(2.9 \%)$ & $\begin{array}{l}90 \\
(1.4 \%)\end{array}$ & 0.15 \\
\hline Eplerenone & $9(0.1 \%)$ & $1(0.7 \%)$ & $8(0.1 \%)$ & 0.061 \\
\hline Spironolactone & $164(2.5 \%)$ & $\begin{array}{l}18 \\
(13.0 \%)\end{array}$ & $\begin{array}{l}146 \\
(2.3 \%)\end{array}$ & $<.0001$ \\
\hline Renin Inhibitors & $13(0.2 \%)$ & $1(0.7 \%)$ & $\begin{array}{l}12 \\
(0.2 \%)\end{array}$ & 0.16 \\
\hline Alpha blockers & $53(0.8 \%)$ & $2(1.5 \%)$ & $\begin{array}{l}51 \\
(0.8 \%)\end{array}$ & 0.40 \\
\hline Clopidogrel & $\begin{array}{l}3983 \\
(61.2 \%)\end{array}$ & $\begin{array}{l}85 \\
(61.6 \%)\end{array}$ & $\begin{array}{l}3898 \\
(61.2 \%)\end{array}$ & 0.92 \\
\hline Nitrates & $\begin{array}{l}2408 \\
(37.0 \%)\end{array}$ & $\begin{array}{l}63 \\
(45.7 \%)\end{array}$ & $\begin{array}{l}2345 \\
(36.8 \%)\end{array}$ & 0.033 \\
\hline Nicotinic acid & $22(0.3 \%)$ & $1(0.7 \%)$ & $\begin{array}{l}21 \\
(0.3 \%)\end{array}$ & 0.43 \\
\hline \multicolumn{5}{|c|}{$\begin{array}{l}\text { Data are } \mathrm{N}(\%) \text {, Mean (SD) or Median (IQR); Abbreviations: ACE inhibitor- angiotensin converting } \\
\text { enzyme, ARB- angiotensin II receptor blocker, AF- atrial fibrillation, BMl- body mass index, eGFR- } \\
\text { estimated glomerular filtration rate, FPG- fasting plasma glucose, } \mathrm{HBA}_{1 \mathrm{c}} \text {-haemoglobin } \mathrm{A}_{1 \mathrm{c}}, 2 \mathrm{HPG}-2 \\
\text { hour plasma glucose, MI- myocardial infarction, SBP-systolic blood pressure, TIA-transient ischaemic } \\
\text { attack, UA- unstable angina }\end{array}$} \\
\hline
\end{tabular}


Table 2

Univariate analysis of risk factors for incident hospitalisation for heart failure (hHF) or hHF/CV death. Statistically significant risk factors are highlighted in bold text.

\begin{tabular}{|c|c|c|c|c|c|c|}
\hline \multirow[b]{2}{*}{ Variable } & \multicolumn{3}{|c|}{$\begin{array}{l}\text { hHF } \\
138 \text { events }\end{array}$} & \multicolumn{3}{|c|}{$\begin{array}{l}\text { hHF/CV death } \\
393 \text { events }\end{array}$} \\
\hline & $\begin{array}{l}\text { Hazard } \\
\text { Ratio }\end{array}$ & $\begin{array}{l}95 \% \text { Confidence } \\
\text { Interval }\end{array}$ & $\begin{array}{l}\mathrm{P}- \\
\text { value }\end{array}$ & $\begin{array}{l}\text { Hazard } \\
\text { Ratio }\end{array}$ & $\begin{array}{l}95 \% \\
\text { Confidence } \\
\text { Interval }\end{array}$ & $\begin{array}{l}P \text { - } \\
\text { value }\end{array}$ \\
\hline $\begin{array}{l}\text { Acarbose (vs. } \\
\text { placebo) }\end{array}$ & 0.89 & $0.64-1.24$ & 0.48 & 0.90 & $0.74-1.10$ & 0.32 \\
\hline Age (years) & 1.10 & $1.08-1.13$ & $\begin{array}{l}<.0001 \\
0.0\end{array}$ & 1.07 & $1.06-1.09$ & $<0.0001$ \\
\hline $\begin{array}{l}\text { Sex: Female (vs. } \\
\text { male) }\end{array}$ & 0.86 & $0.58-1.27$ & 0.44 & 0.71 & $0.56-0.91$ & 0.0064 \\
\hline $\begin{array}{l}\text { Ethnicity: Han (vs. } \\
\text { not Han) }\end{array}$ & 1.35 & $0.43-4.24$ & 0.61 & 1.14 & $0.66-1.99$ & 0.64 \\
\hline $\mathrm{HBA}_{1 \mathrm{c}}(\%)$ & 1.00 & $0.78-1.29$ & 0.99 & 0.95 & $0.82-1.10$ & 0.45 \\
\hline FPG (mmol/L) & 0.92 & $0.74-1.15$ & 0.45 & 0.92 & $0.81-1.05$ & 0.20 \\
\hline 2HPG (mmol/L) & 1.03 & $0.89-1.20$ & 0.70 & 1.00 & $0.91-1.09$ & 0.91 \\
\hline $\mathrm{BMI}\left(\mathrm{kg} / \mathrm{m}^{2}\right)$ & 0.98 & $0.92-1.03$ & 0.36 & 0.96 & $0.92-0.99$ & 0.0057 \\
\hline $\begin{array}{l}\text { Waist } \\
\text { Circumference } \\
\text { (cm) }\end{array}$ & 1.00 & $0.98-1.02$ & 0.78 & 1.00 & $0.99-1.01$ & 0.67 \\
\hline $\mathrm{SBP}(\mathrm{mmHg})$ & 1.00 & $0.98-1.01$ & 0.47 & 1.00 & $1.00-1.01$ & 0.66 \\
\hline $\begin{array}{l}\text { Plasma Creatinine } \\
(\mu \mathrm{mol} / \mathrm{L})\end{array}$ & 1.03 & $1.02-1.03$ & $\begin{array}{l}< \\
0.0001\end{array}$ & 1.02 & $1.02-1.03$ & $<0.0001$ \\
\hline $\begin{array}{l}\text { Haemoglobin } \\
(\mathrm{g} / \mathrm{dL})\end{array}$ & 0.97 & $0.96-0.98$ & $\begin{array}{l}<.0001 \\
0.0\end{array}$ & 0.99 & $0.98-0.99$ & 0.0002 \\
\hline \multicolumn{7}{|l|}{ Smoking Status } \\
\hline Ex vs. Never & 0.82 & $0.58-1.17$ & 0.28 & 1.15 & $0.93-1.43$ & 0.20 \\
\hline Current vs. Never & 0.88 & $0.51-1.50$ & 0.64 & 1.20 & $0.87-1.63$ & 0.26 \\
\hline
\end{tabular}

Abbreviations: AF- atrial fibrillation, $\mathrm{BMI}$ - body mass index, FPG- fasting plasma glucose, $\mathrm{HBA}_{1 \mathrm{c}}$ haemoglobin $\mathrm{A}_{1 \mathrm{c}}$, $\mathrm{HPG}$ - 2-hour plasma glucose, Ml- myocardial infarction, SBP-systolic blood pressure, TIA-transient ischaemic attack, UA- unstable angina 


\begin{tabular}{|c|c|c|c|c|c|c|}
\hline \multirow[b]{2}{*}{ Prior HF } & \multicolumn{3}{|c|}{$\begin{array}{l}\text { hHF } \\
138 \text { events }\end{array}$} & \multicolumn{3}{|c|}{$\begin{array}{l}\text { hHF/CV death } \\
393 \text { events }\end{array}$} \\
\hline & 6.57 & $4.31-10.01$ & $\begin{array}{l}< \\
0.0001\end{array}$ & 3.81 & $2.82-5.15$ & $<.0001$ \\
\hline Prior MI & 1.64 & $1.17-2.30$ & 0.0037 & 1.64 & $1.34-2.00$ & $\begin{array}{l}< \\
0.0001\end{array}$ \\
\hline Prior UA & 0.53 & $0.36-0.77$ & 0.0009 & 0.64 & $0.52-0.80$ & $\begin{array}{l}<.0001 \\
\end{array}$ \\
\hline Prior stable angina & 1.30 & $0.90-1.89$ & 0.17 & 0.97 & $0.76-1.23$ & 0.80 \\
\hline Prior AF & 4.92 & $3.14-7.70$ & $\begin{array}{l}< \\
0.0001\end{array}$ & 2.63 & $1.88-3.68$ & $\begin{array}{l}< \\
0.0001\end{array}$ \\
\hline Prior stroke/TIA & 1.33 & $0.74-2.40$ & 0.35 & 1.97 & $1.46-2.66$ & $<.0001$ \\
\hline Prior hypertension & 0.98 & $0.69-1.39$ & 0.90 & 1.43 & $1.00-2.05$ & 0.053 \\
\hline \multicolumn{7}{|c|}{$\begin{array}{l}\text { Abbreviations: AF- atrial fibrillation, BMI- body mass index, FPG- fasting plasma glucose, } \mathrm{HBA}_{1 \mathrm{c}}{ }^{-} \\
\text {haemoglobin } \mathrm{A}_{1 \mathrm{c}} \text {, } 2 \mathrm{HPG} \text { - 2-hour plasma glucose, MI- myocardial infarction, SBP-systolic blood } \\
\text { pressure, TIA-transient ischaemic attack, UA- unstable angina }\end{array}$} \\
\hline
\end{tabular}


Table 3

Significant risk factors in multivariate models for incident hospitalisation for heart failure (hHF) and for hHF/CV death

\begin{tabular}{|c|c|c|c|c|c|c|}
\hline \multirow[b]{2}{*}{ Variable } & \multicolumn{3}{|c|}{$\begin{array}{l}\text { hHF } \\
138 \text { events }\end{array}$} & \multicolumn{3}{|c|}{$\begin{array}{l}\text { hHF/CV death } \\
393 \text { events }\end{array}$} \\
\hline & $\begin{array}{l}\text { Hazard } \\
\text { Ratio }\end{array}$ & $\begin{array}{l}95 \% \\
\text { Confidence } \\
\text { Interval }\end{array}$ & $\begin{array}{l}\mathrm{P} \\
\text { value }\end{array}$ & $\begin{array}{l}\text { Hazard } \\
\text { Ratio }\end{array}$ & $\begin{array}{l}95 \% \\
\text { Confidence } \\
\text { Interval }\end{array}$ & $\begin{array}{l}\mathrm{P} \\
\text { value }\end{array}$ \\
\hline Age (per 10 years) & 1.89 & $1.52-1.36$ & $<.0001$ & 1.81 & $1.59-2.04$ & $<.0001$ \\
\hline $\begin{array}{l}\text { Plasma creatinine } \\
\text { (per } 10 \mu \mathrm{mol} / \mathrm{L})\end{array}$ & 1.20 & $1.12-1.28$ & $<.0001$ & 1.16 & $1.11-1.21$ & $<.0001$ \\
\hline Haemoglobin $(\mathrm{g} / \mathrm{dL})$ & 0.98 & $0.97-0.99$ & 0.0033 & $\ldots$ & $\ldots$ & $\ldots$ \\
\hline Prior HF & 3.08 & $1.96-4.85$ & $<.0001$ & 2.29 & $1.67-3.13$ & $<.0001$ \\
\hline Prior MI & 1.74 & $1.24-2.44$ & 0.0014 & 1.71 & $1.40-2.09$ & $<.0001$ \\
\hline Prior AF & 2.53 & $1.58-4.04$ & 0.0001 & 1.62 & $1.15-2.28$ & 0.0059 \\
\hline Prior stroke/TIA & $\ldots$ & $\ldots$ & $\ldots$ & 1.53 & $1.13-2.08$ & 0.0041 \\
\hline
\end{tabular}

Table 4

Deaths following first hospitalisation for heart failure event, overall, and for those with or without prior heart failure (HF)

\begin{tabular}{|lllll|}
\hline & \multicolumn{2}{l}{ CV Death } & \multicolumn{2}{l|}{ All-cause mortality } \\
\hline & Deaths & Proportion & Deaths & Proportion \\
\hline $\begin{array}{l}\text { Overall } \\
(\mathrm{n}=138)\end{array}$ & 53 & $38 \%$ & 58 & $42 \%$ \\
\hline $\begin{array}{l}\text { Prior HF } \\
(\mathrm{n}=27)\end{array}$ & 13 & $48 \%$ & 14 & $52 \%$ \\
\hline $\begin{array}{l}\text { No prior HF } \\
(\mathrm{n}=111)\end{array}$ & 40 & $36 \%$ & 44 & $40 \%$ \\
\hline
\end{tabular}

\section{Figures}




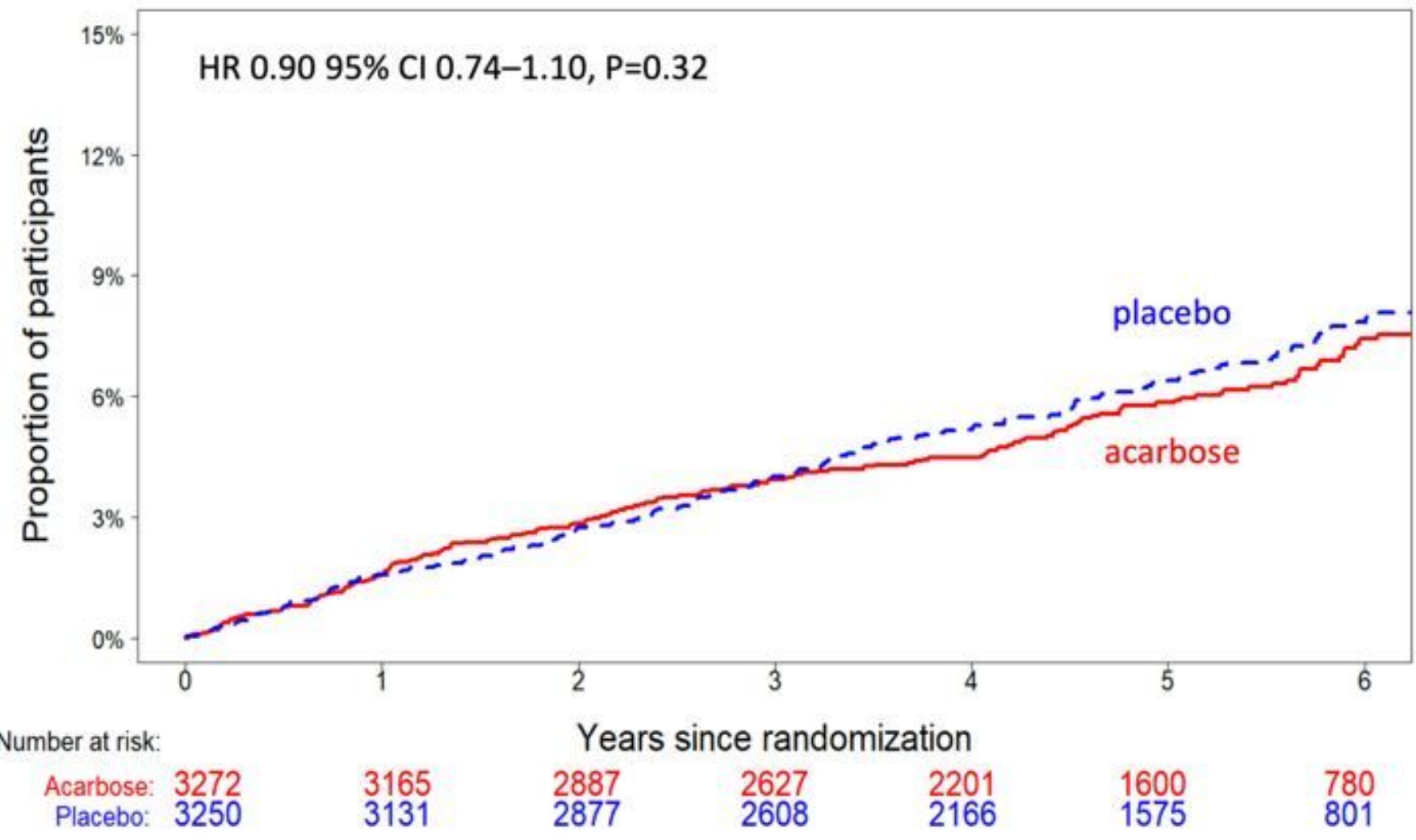

\section{Figure 1}

Kaplan-Meier plot of hospitalisation for heart failure (hHF)/CV death, split by participants allocated to acarbose or placebo. 

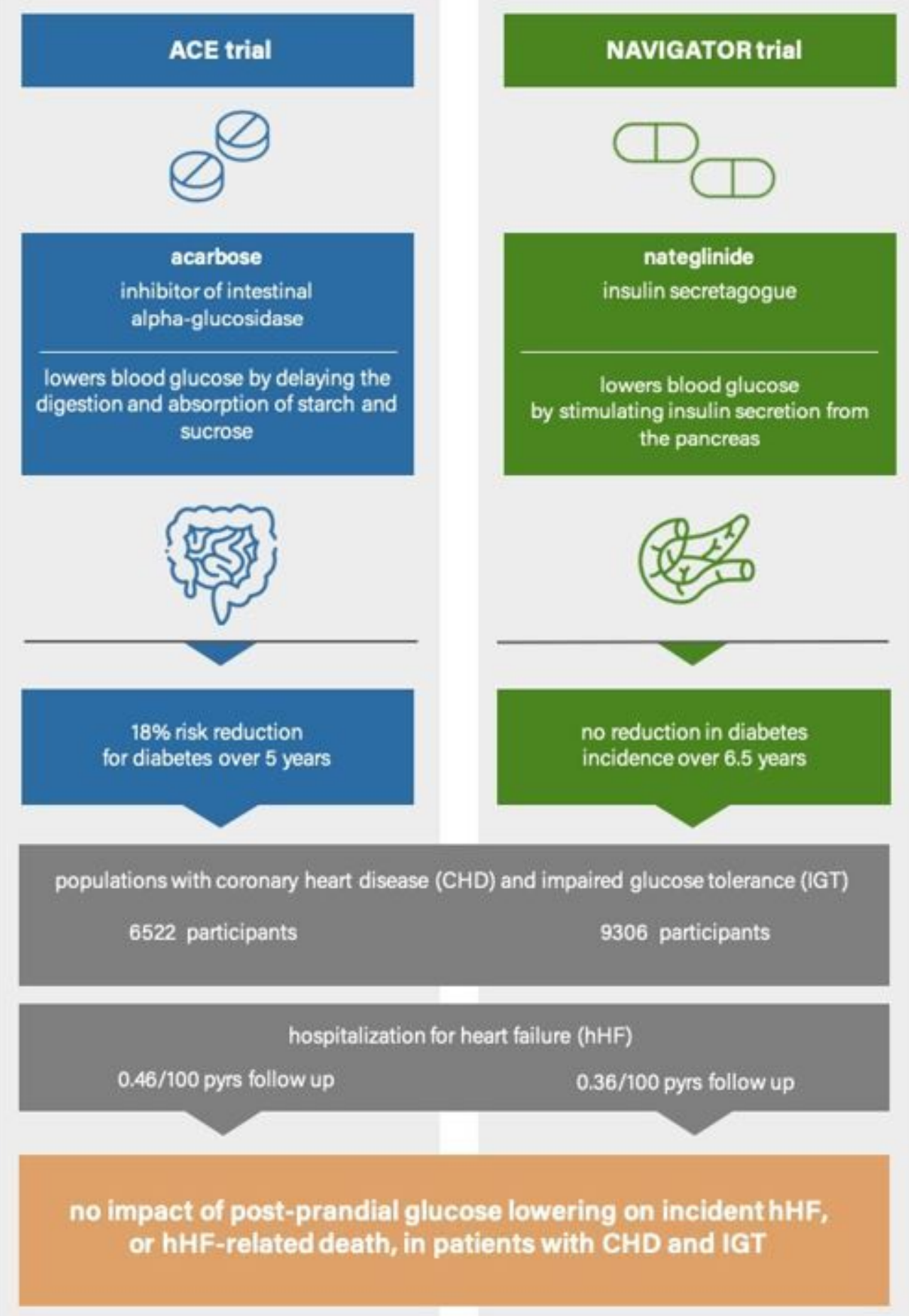

\section{Figure 2}

Therapies that lower post-prandial glucose excursions examined in the ACE and NAVIGATOR trials had no impact on incident hospitalisation for heart failure (hHF) or hHF-related death.

\section{Supplementary Files}


This is a list of supplementary files associated with this preprint. Click to download.

- 200514ACE015CoverletterCardiovascularDiabetologyRRH.docx 